\title{
Risky (farm) business: Perceptions of economic risk in farm succession and inheritance
}

\author{
Brian Leonard ${ }^{\mathrm{a}, \mathrm{b}, *}$, Maura Farrell $^{\mathrm{a}}$, Marie Mahon ${ }^{\mathrm{a}}$, Anne Kinsella ${ }^{\mathrm{b}}$, Cathal O'Donoghue \\ ${ }^{a}$ School of Geography, NUI Galway, Ireland \\ ${ }^{\mathrm{b}}$ Teagasc Rural Economy and Development Programme, Ireland \\ ${ }^{\mathrm{c}}$ College of Arts, Social Sciences and Celtic Studies, NUI Galway, Ireland
}

\section{Introduction - the complexity of farm generational renewal}

Even though an on-going concern of EU (European Union) policymakers around generational renewal in agriculture has been articulated over the past decade or so, it has not, as of yet, resulted in an effective policy response from any member state. Generational renewal, meaning the successive retirement of older farmers who are replaced by a younger or newer cohort of farmers, is viewed as essential for a progressive agricultural sector. Even though farmers constantly upskill as part of their profession, the reality of a sector that is relatively closed to new entrants in comparison to other occupations is regarded as detrimental to its longer-term competitiveness in terms of gradual loss of creativity, innovation and transformation (Rovny, 2016; Kimhi and Nachlieli, 2001). Zagata and Sutherland (2015) discuss the perceived need for an influx of young farmers into European agriculture as linked to the 'modernist agenda' (p. 40) in agriculture where increased efficiency and production will lead to economic development. This contention is based upon studies that have identified a correlation between young farmers and higher productivity/efficiency (Williams, 2006; Howley et al., 2012). In addition to productivity levels, more importantly, younger farmers have been linked to an increase in environmental measures at farm level (Ward and Lowe, 1994). Siebert et al. (2006) assert that younger and better educated farmers tend to be well represented in adopters of agri-environmental measures. In tandem with this Mills et al. (2017) found that in some cases successors were at odds with their parents when trying to increase the level of environmental activity on farm. In their study of farm restructuring in England, Lobley and Potter (2004) also found that younger farmers fell into a grouping of more dynamic farmers, while older farmers tended to be less likely to undertake significant restructuring. Within the EU, the high number of older farmers is mirrored by a lower figure for younger farmers in the sector (Zagata and Sutherland, 2015). While some of this can be attributed to general societal trends such as rising life expectancy and an increase in the amount of time spent by younger persons in education; farm demographics still exhibit a greater degree of complexity compared to the general workforce. Entering farming as a career is often the result of land transfer by a relative, for example a parent or grandparent; i.e. farm enterprises are passed down in a generational manner (De Haan, 1994; Hennessy and Rehman, 2007). These transfers take place only when the incumbent farmer feels fully ready to do so, often resulting in the deferral of farm transfer until after their death (Conway et al., 2017). This prioritises the personal wishes and visions of the incumbent (which usually incorporate a mix of cultural, social and economic concerns) as opposed to a transfer prioritising the ongoing success of the farm as a business enterprise. With the development trajectory of EU agriculture based strongly on the success of family farms in most member states, Lobley et al. (2010) assert that without generational renewal 'the risk is that the cornerstone of agricultural businesses in these countries will fail to meet national and global expectations' (p. 60) with serious implications for the sector as a whole.

Farmers have been supported for several decades by a range of CAP (Common Agricultural Policy) measures, the aim of which has been to sustain the agricultural sector by essentially supplementing farm incomes in ways that work contrary to market efficiencies. Matthews (2014) notes the importance of CAP payments at present in particular given the level of income volatility linked to fluctuating commodity and output prices. In addition, farmers in receipt of a Basic Farm Payment (BFP) can choose to join agri-environmental schemes which provide further income in return for farming in a sustainable manner that avoids environmental degradation. Research has indicated a link between farm payments and the impediment of farm transfer, Leonard et al. (2017a) note that subsidies do not encourage farmers to consider engaging in farm transfer processes because farmers can receive direct payments while engaging in a minimum level of agricultural activity and receive a state pension alongside these payments. In tandem with this Breustedt and Glauben (2007) assert that increased subsidy payments are linked to a reduction in the number of farmers exiting. Payments to farmers receiving a BFP can vary, although in general, larger farms receive higher BFPs despite the higher income they accrue. Beef farmers in Ireland, for example, are particularly dependant on farm payments, with subsidies making up over $100 \%$ of farm income in

\footnotetext{
* Corresponding author. School of Geography, NUI Galway, Ireland.

E-mail address: Brian.leonard2@hotmail.com (B. Leonard).
} 
many cases (Dillon et al., 2017). In contrast to the Irish system, Swiss farmers cannot receive direct payments and a pension simultaneously, resulting in many farms being transferred once a farmer reaches retirement age (Contzen et al., 2017). Similarly in Germany a 'Hofabgabe Klausel' (farm transfer clause) means that farmers must transfer their farm assets if they wish to receive a farmers pension (Mehl, 2009).

There has been limited investigation of how the perceptions of economic risk associated with farm transfer affects farmers' decisions to proceed or not with transfer. Using the example of Ireland, this paper explores this issue, focusing on the decision-making process of a sample of individual farmers. It first outlines concepts of risk and their application to the agricultural sector, and illustrates how these provide an explanatory framework for the ways that farmers make decisions, and particularly economic decisions, at individual family farm level that have implications for land transfer. Notably this piece of work builds part of a wider research project which looks at the economic and policy aspects of farm transfer; initially analysis was undertaken using a quantitative approach which modelled policy surrounding land transfer taxation and farm partnerships (Leonard et al., 2017a, 2017b). This then allowed the research to move to the farm level having ascertained wider trends regarding economic factors affecting farm transfer decision making. For this paper, a qualitative approach is applied focusing on the two most dominant farm systems (beef and dairy) in order to ascertain the opinions of farmers on the economic challenges of contemplating farm transfer. Information gathered through problem centred interviews is examined using thematic analysis to outline the main financial concerns farmers have and how these indicate whether or not there is a risk perception associated with farm transfer. Finally, key implications from this research for generational renewal policy are discussed.

\section{Risk - constructivist versus rationalist perspectives}

The following sections discuss key academic perspectives on the construction of risk in order to develop a framework for analysis of how this occurs in the context of contemporary farming, under complex conditions of agricultural change impacting from the global down to the very local level and its influence on farmers' decision-making. It first outlines constructivist and rationalist understandings of risk, followed by the distinction between risk and uncertainty as a further means to identify what issues exactly drive farmers' decision-making and the role that different forms of knowledge (or lack of it) play in their assessment. It then examines more specific literature on the phenomenon of risk and uncertainty in agricultural studies mainly from institutional and policy perspectives.

To date, the main focus of agricultural risk research has been around environmental, health and safety, and economic factors. There has been limited research conceptualising farm succession and inheritance as a risk facing individual farms and the agricultural sector as a whole. Discourses surrounding risk perception are drawn from two dominant approaches; constructivist and rationalist. Constructivist approaches view risks as contextual and a result of social creation (Birkholz et al., 2014). Here, Kirby (1990) explains that risk perception 'is usually dependent upon a social representation, which can be defined as a culturally conditioned way of viewing the world' (p. 282), i.e. the perception of risk is heavily influenced by the social and institutional environment in which individuals are embedded. Rationalist theories on the other hand are centred on the notion that the presence of a hazard results in a rational judgement about the avoidance of a potential hazard (Birkholz et al., 2014). The rationalist approach implies that risk perception is measurable and can be quantified (Scolobig et al., 2012), based on full information about the issue in question, and on the pros and cons of alternatives (Zinn, 2017; Adams, 1995). On the strongly economic end of the risk spectrum, Just (2001) asserts that risk is 'the case where the distribution of outcomes is known either a priori or statistically through past experience' (p. 1131). One main critique of a rationalist approach would be the assumption that human behaviour follows a rational pattern. The constructivist approach on the other hand aims to explain how social agents create risk in a given society (Tierney, 1999), leading to more affective and subjective questions of 'interests, power, and social conflict' (Clarke and Short, 1993, p. 379); in other words, an emphasis on who constructs these risks and why.

It is therefore important to look for the means by which risks are created, as these can influence the narrative about the level of actual threat they pose. Klinke and Renn (2002) use the example of how relatively minor public risks may be sensationalised via media narratives, leading to exaggerated public reactions and demands for their management. Similarly, Botzen et al. (2009) note that public perceptions of risk may vary considerably from that of an expert in a particular field. Birkholz et al. (2014) suggest that social systems such as 'culture, institutions, organisations, values, beliefs' (p.17) into which people are socialised are interwoven with risk constructs. In examining the underlying processes that give rise to such constructs, Klinke and Renn (2002) identify qualitative risk characteristics such as trust in regulatory agencies and risk-handling institutions and social and cultural beliefs associated with the cause of risk or the risk-handling actors. Such characteristics generally pertain to individual interactions on which individuals build their perceptions pertaining to a particular risk source.

\section{Risk and uncertainty in an agricultural decision-making context}

The agricultural sector is subject to a myriad of risks to the extent that Kaupilla et al. (2013) cite risk as 'an inherent part of agricultural production' (p. 42). Likewise, Buckwell et al. (2017) note the high level of risk associated with farming, with particular note for the number of farms that are unable to adequately deal with risk. Within agricultural operations, the response to risk depends upon the risk attitude of the individual as well as factors such as the farm's resource base, financial condition, organization, local and national markets, and stage in the farmer's life cycle (Fleisher, 1990). Within a society of risk shaping, each actor may wish to sensationalise a risk pertinent to them (Beck, 1992). One issue that emerges in much of the literature on risk in agriculture is the difference between risk on one hand and uncertainty on the other, even though the two terms are frequently used interchangeably. A general consensus would be that risk is in some way quantifiable or that the results of taking a risk can be put into some form of probability, while uncertainty implies a lack of knowledge regarding what will happen; in other words, uncertainty differs from risk in that with uncertainty the odds of an outcome are not known (Just, 2001; Adams, 1995). In the context of forms of risk and uncertainty in agriculture, Hardaker et al. (2015) describe uncertainty as 'imperfect knowledge' (p. 4) while risk constitutes 'uncertain consequences' (p. 4). Such consequences generally pose a threat in some way, thus attaching a value to risk outcomes. Therefore, approaching a situation without possessing full knowledge means there can be no assumptions or calculations as to what outcomes might occur (i.e. uncertainty), whereas having knowledge of possible consequences means there can be some expectations for a set of outcomes (i.e. risk).

While it has been argued that farmers are generally risk averse (Groom et al., 2008) in many areas, there has been very little research investigating whether or not farmers perceive succession and inheritance processes as a risk. Hardaker et al. (2015) assert that the risk averse behaviour of farmers is evident in their decisions. For example, some farmers have a preference for certain farm systems where there are more options for diversification, making it difficult to foresee what decisions they might take. Thus, the calculation of risk may be possible but the level of uncertainty is incalculable and has a clear influence on farmer decision making. Barlett (1980) furthermore contends that 'local realities will always distort the mathematical curves' (p. 8). It is at this local level where individuals form their perceptions of risk (or 
uncertainty), thus the importance of local circumstance must be emphasised along with external forces.

In the case of this research, making the distinction between the two phenomena as two different but interlinked parts of a complex decisionmaking process enables a more accurate analysis of the issues underlying the perception of risk and the decisions that result from them, particularly the problem of the unknown and how this is assessed and evaluated by farmers. In the case of farm succession and inheritance the calculation of probabilities in terms of farm transfer outcomes may be impossible; for example, farmers will be uncertain regarding future policy change that may affect farm transfer as they have no means by which to assess possible changes.

\subsection{Institutional risk shaping in agriculture}

Risk perceptions are formed based on the society in which an individual is embedded; in most instances the media and political actors attempt to place certain risks in the public eye with a view to economic or political gain. Hardaker et al. (2015) note that changes in policy/ regulation governing agriculture can have a profound effect at farm level. They describe this as institutional risk that also incorporates political, sovereign and contractual risks. Most of these sources of risk stem from government levels. The main policy instruments available to governments in shaping the agricultural sector are financial, i.e. tax relief or grant based schemes. Essentially, financial incentives are used to encourage individuals to undertake measures that achieve strategic government aims. This has been achieved in the past resulting in widespread change in agriculture; for example, the policy changes that encouraged production from the 1970s onwards, reflecting national government and EU-level control over the sector and the creation of risk perceptions around food security. This productivist agenda also led to widespread negative impacts for human and animal welfare (e.g. BSE) and to environmental degradation (Wilson, 2001; O'Connor et al., 2006). At present, farming practices such as environmental conservation are encouraged using agri-environmental schemes, with these schemes generally benefiting farmers economically (Morris and Potter, 1995). Entering financially incentivised schemes has been linked to the reduction of uncertainty around income for farmers, thus decreasing their perceived economic risk (Koundouri et al., 2009) (i.e. the idea that a guaranteed payment to supplement farm income means less reliance on a volatile market). Koundouri et al. (2009) also refer to the importance of taking account of farmers' own attitudes to the risks involved in new policies, asserting that projected policy outcomes will vary accordingly. This issue of the varied perceptions of risk at the more individual level is also discussed by Pieczka and Escobar (2012) who assert that policies must reflect ground level issues in order to be successful.

\subsection{Economic incentives for generational renewal}

Historically, there has been no substantial long term policy put in place which has attempted to encourage a timely transfer of farms or even to assist in the process of shifting managerial control to younger farmers over time. Early Farm Retirement Schemes (EFRS) are one method used in an attempt to encourage generational renewal, with schemes being optional and mainly taken up by Ireland, France and Greece (Davis et al., 2009). Whilst there have been three rounds of an EFRS in Ireland, in 1993, 2000 and 2007, all were short lived and said to have been of 'little value for money' (Hennessy, 2014). From a noneconomic perspective, Conway et al. (2016) found that these schemes did not consider the emotional implications of asking farmers to 'exit farming forever' as part of the terms and conditions, but were instead 'excessively preoccupied with financial incentives' (p. 174), which ultimately failed to deliver on significantly increased levels of farm transfer. France and Greece also initiated an EFRS and as with Ireland, were found to be of poor economic value, with farmers entering the scheme only a few years from retirement age (Caskie et al., 2002). In the UK, Ingram and Kirwan (2011) evaluated the Fresh Start Initiative which matched new entrant farmers with retiring farmers as a means of giving younger farmers a start and older farmers a gradual exit strategy; however, this was not considered a success, with older farmers reluctant to work with young farmers that were not blood relatives or closely acquainted. In the case of New Zealand, the dairy industry has a well-developed career structure which gives young farmers the opportunity to begin farming and has exit schemes available for older farmers such as phased exit strategies like share milking arrangements (CIAS, 1996). Many Dutch farms are in partnerships which facilitate the process of gradual succession (NRN, 2012), a process which Macken-Walsh (2010) suggests could potentially benefit young Irish farmers, becoming a clear entry point into farming. However, there are no strong Irish policy incentives to join a farm partnership and until spring 2015, registered partnerships were only an option to those operating dairy and tillage systems. In the Flemish case, developing a 'JongerenActiePlan' (Youth Action Plan) has been encouraged and entails the stimulation of young farmer education and the provision of advice during farm transfer (Calus et al., 2008). While a scheme like this would be positive, getting to the point of transfer at an earlier stage would still remain an issue. In all, the introduction of mandatory succession/inheritance policy at CAP level may be a method of reducing the age of the farm population, but the question remains as to exactly what kind of policy could be introduced, and whether economic incentives would entice farmers to consider succession and inheritance options.

\subsection{Distinguishing between succession, inheritance, and retirement}

While the processes of succession, inheritance and retirement are inextricably linked, it is important to note that differences exist between the individual stages which form the basis for generational renewal. Succession denotes the transfer of managerial control from a farmer to their successor; this can take place over time, often over the lifetime of a successor. Inheritance refers to the legal transfer of assets to a successor; generally this takes places following succession (Potter and Lobley, 1996). The final process affecting the overall farm transfer is that of retirement, while succession and inheritance relate more to a successor, retirement specifically impacts the outgoing farmer. In most instances retirement from farming takes the form of semi-retirement, while a number of farmers do not engage in any form of retirement (Uchiyama et al., 2008). The inescapable linkages that exist between succession, inheritance and retirement mean that the exclusion of any one could lead to a set of results that does not appropriately address the current issues in this field. Notably, Bertoni and Cavicchioli (2016) assert that the process of succession should be considered in the context of the wider economic and financial environments in which farms are operating.

\subsection{Risk and uncertainty in farm succession and inheritance}

Lobley and Baker (2012) assert that 'intergenerational farm transfers are a fundamental aspect of the sustainability of family farming' (p. 9). The farm transfer process however, is fraught with difficulties, several of which are of an economic nature. For instance, farmers transferring land to their successors require a revenue stream once they have forgone their farm income, and in many cases, they tend to continue relying financially on the farm once they have handed over ownership to a successor (McLeod, 2012). Errington (2002) notes that many farmers avoid transferring managerial control to a successor to protect their income beyond retirement age. This stems from a historical lack of planning for retirement income in the farming community; a point illustrated by Weston (1977) who also highlights that a lack of such planning was more prominent for smaller farms. Whitehead et al. (2012) note that the need for income when entering retirement/semiretirement is inescapable and sources of such income vary based on 
location; for example farmers in Canada were more likely to sell their farms, while those in England more commonly rely on private pensions. Regardless of the source of said income, the farm plays a role in financing it.

Ward and Lowe (1994) assert that farm succession and the desire to transfer the farm to a family member are constructed in a social manner, referring to succession as a 'social goal' (p. 175) that aims to merge family and business. In turn this social decision becomes economic as it is affected by income, inheritance taxation, and legalities associated with land transfer. Fischer and Burton (2014) also highlight the socially constructed and hence subjective nature of succession ideals, while referring to the countless studies that have categorised and quantified factors that affect the process. For example, File and Prince (1996) note that many family businesses can be subject to estate taxes which can place a burden on family members in a succession context. In the case of farming, however, planning for farm transfer could result in little or no tax being paid; yet it remains a stated source of uncertainty for farmers contemplating retirement (Leonard et al., 2017a). Fischer and Burton (2014), and Veerman et al. (2016) observe that no two farms respond in the same way to any source of influence on the succession/inheritance decision, and that awareness of risks and the need for risk management vary considerably among farmers. This perspective is also emphasised by Smit and Skinner (2002) whose work on agricultural adaptation to climate change risk establishes that adaptations as a means to mitigate against such risks vary widely in line with ongoing farm practices, public policy decisions, and other political, economic and social conditions. The concept of life stages has a very strong influence on farm succession and inheritance, with Barclay et al. (2012) describing 'critical events' such as marriage, death and illness as triggers for the processes of succession and inheritance to be undertaken. One of the most important life stages (or 'critical events') discussed by academics is the stage in which a successor marries or has their first child. According to Wilkinson (2012), when a successor marries, the family farm's life span is assumed to be extended due to the introduction of another generation. Stage of life and the resulting changes in personal and family circumstances. However, concerns about divorce and the risk of a farm being divided as part of a settlement is a significant concern to farmers (Price and Evans, 2006). While the sale of the family farm presents an economic risk (i.e. a measurable outcome), the likelihood of marital breakdown is immeasurable and thus is by nature a form of uncertainty (Just, 2001).

\subsection{Influence of farm characteristics on transfer}

The characteristics of a farm can have a strong influence on succession and inheritance outcomes and how the risks attached to same are assessed, with factors that influence farm income (such as farm size and system) having the most impact on the processes. Uchiyama et al. (2008) found that farm size influenced succession, with successors on smaller farms being more likely to have employment outside of the farm, thus decreasing the likelihood of them entering farming. Chang (2013) raises a similar notion in stating that young people have become less interested in farming as a result of the low income that can often be accrued from agriculture. Taken in conjunction with the ideas of Uchiyama et al. (2008) regarding successors on smaller farms finding off farm employment, the probability is that smaller farms will have lower incomes, meaning attracting a successor to such a holding could be challenging. As young farmers become increasingly aware of the higher income and better lifestyle possibilities outside of farming it may become more difficult to attract a new generation to take on family farms (Cavicchioli et al., 2018; Fischer and Burton, 2014; Wilkinson, 2012).

Larger farms are more likely to have identified a successor, with Calus et al. (2008) revealing that farms with higher asset values were more likely to have positive succession prospects. Glauben et al. (2004) for example found that more profitable farms in Germany have a 'significantly higher probability of being transferred within the family' (p. 7). In essence, there is a very clear link between farm income/viability and likelihood of having a successor. In their study on farm restructuring, Lobley and Potter (2004) found that of the low number of respondents who planned to exit farming, the majority were older farmers operating smaller farms. This implies that farm size may affect the exit and entry rate, i.e. that successors are more tempted to take on larger farms, but that these may not be coming available either in sufficient numbers or quickly enough.

In considering succession and economic risk, Mishra and El-Osta (2007) emphasise the fact that succession planning for a family farm is as much about a farm business management strategy as it is about continuity of management. They examine farm characteristics to assess how they affect succession decisions, because these are linked to the value of the farm for the potential successor. Measuring the financial condition of the farm (levels and sources of wealth and debt, for example) along with farm size provided an indication of the likelihood of a succession plan being in place; i.e. these issues constituted a form of risk assessment that in turn influenced succession decisions linked to the farm as a business (see also Mishra et al., 2010). Glauben et al. (2004) also examine this notion of economic risk in succession. Their focus is also on the farm as a family firm, and the extent to which practices such as intergenerational risk-sharing of financial burdens on income flows or in relation to taxation support the farm business and facilitate succession. They examine the timing of succession planning based on a range of farm characteristics as a means to mitigate financial risks. This issue of farm characteristics, along with policy and macroeconomic conditions and how they influence an exit from farming have examined by Breustedt and Glauben (2007). They found that structural changes influenced by measures like subsidy payments from the EU reduced the decline in farm numbers, reflecting a form of economic risk reduction for farmers.

Notably the effects of personal and emotional factors on farm transfer decision making have been comprehensively investigated, in the case of the wider approach to farm succession and inheritance these elements are important to reflect on in tandem with economic considerations. These factors include place identity (Downey et al., 2017), loss of symbolic capital (Conway et al., 2017), and emotional attachment to the farm (Suess-Reyes and Fuetsch, 2016). While these factors are of key importance, this research focuses on the economic risk elements of farm transfer and their contribution to a decision that is affected by a myriad of factors.

\section{Methodology}

A purposive sampling approach was employed for this research to ensure that farms with differing income levels were targeted, in particular beef and dairy farms. These are the two most dominant farm systems in Ireland, with beef farmers receiving a significantly lower average income in comparison to dairy. Average Family Farm Income ${ }^{1}$ for dairying stands at $€ 66,788$, while beef (cattle rearing) systems accrue $€ 12,568$ on average (figures based on 3 year average for period 2015-2017 using Teagasc National Farm Survey data - Hennessy and Moran, 2016, Dillon et al., 2017; Dillon et al., 2018). In addition to this, the locations of these farm systems tend to be regionalised, with a high concentration of dairy farms in the South, and many of the beef farms based in the West. This is evidenced by the number of dairy farms in county Cork, which stands at 4500 (O'Connor and Keane, 2014). In comparison Mayo is home to just 360 dairy farms (Mayo County Council, 2019). In brief, this regionalisation of farm systems is a result of higher land quality in the South in the first instance, but has also been shaped by a range of policy and market changes that have taken place historically (Matthews, 2014). Policy changes such as the

\footnotetext{
${ }^{1}$ Family Farm Income denotes gross output less total net expenses.
} 
introduction of payments which were decoupled from production and the introduction of milk quotas are some examples of the tapestry of changes that have led to the structure and dispersion of Irish agriculture as it is today.

For the overarching research project, a mixed methods approach was used. Quantitative methods were employed to assess broader trends in farm succession and inheritance, focusing on the operation and impacts of policy-led financial instruments, while the qualitative methods in the form of Problem Centred Interviews (PCI) were used to gain a deeper understanding of those trends. Initially a quantitative approach using hypothetical microsimulation was applied to investigate the policy drivers of farm succession and inheritance (Leonard et al., 2017a). Using this data, the example of farm partnerships as a documented potential means of promoting farm succession and inheritance was modelled (Leonard et al., 2017b). This paper incorporated a widening discussion on the evident problems inherent in any widespread application of farm partnerships as a possible solution to the farm transfer problem including policy inflexibility and the negative financial implications for different categories of farmer. From a risk perspective, the complexity of farm systems and possible intricacies of partnership arrangements meant that the potential decision-making strategies of farmers could not be comprehended by quantitative methods alone. The findings of the quantitative element in turn led to the development of further enquiry instruments of a more qualitative nature, designed to investigate the more socially-constructed aspects of risk assessment and decision-making by farmers.

\subsection{Farm demographics data}

Central Statistics Office (CSO) data was used to map the number of older and younger farmers by county. Figs. 1 and 2 illustrate a concentration of younger farmers in the South, while a higher number of older farmers appear in the West. Based on these statistics counties Mayo and Cork were chosen as study locations. Cork exhibited a high number of younger famers (8\% under 35) and a lower incidence of older farmers $(20.8 \%$ over 65$)$, while Mayo was the inverse with only $4.3 \%$ under 35 and $32.8 \%$ over 65 . This sample selection allowed for comparison between locations as well as between farm systems. With initial assistance from Teagasc in identifying key individuals, and then using a snowballing technique, 24 farmers in total were interviewed, 12 from Cork (6 East, 6 West), and 12 from Mayo (6 North, 6 South). All farmers were given pseudonyms to ensure anonymity. Of the farmers interviewed only two did not have children. In terms of employment status, the majority of beef farmers were retired from off-farm jobs, while dairy farmers were exclusively full-time farming or semi-retired from farming (Table 1). Of all the farmers contacted for interview, only two did not wish to participate.

\subsection{Problem centre interviews}

Given the nature of this research topic, the Problem Centred Interview (PCI) was deemed the most appropriate approach to evidence collection. Farms, and in particular farm transfers, are idiosyncratic and thus require an individual level of investigation that allows for the interviewees to describe their specific farm situation. PCI is a qualitative approach, a key benefit of which is to allow for an open narrative at the beginning, followed by a thematic interview (Scheibelofer, 2005). Witzel and Reiter (2012) outline four key parts of a PCI approach which include a short questionnaire, interview guideline, recordings and a postscript (p. 3). In the case of this research, the aim of the open narrative section was to establish each farmer's perception of risk and explore their concerns around farm finances, with a particular focus on

County Mayo

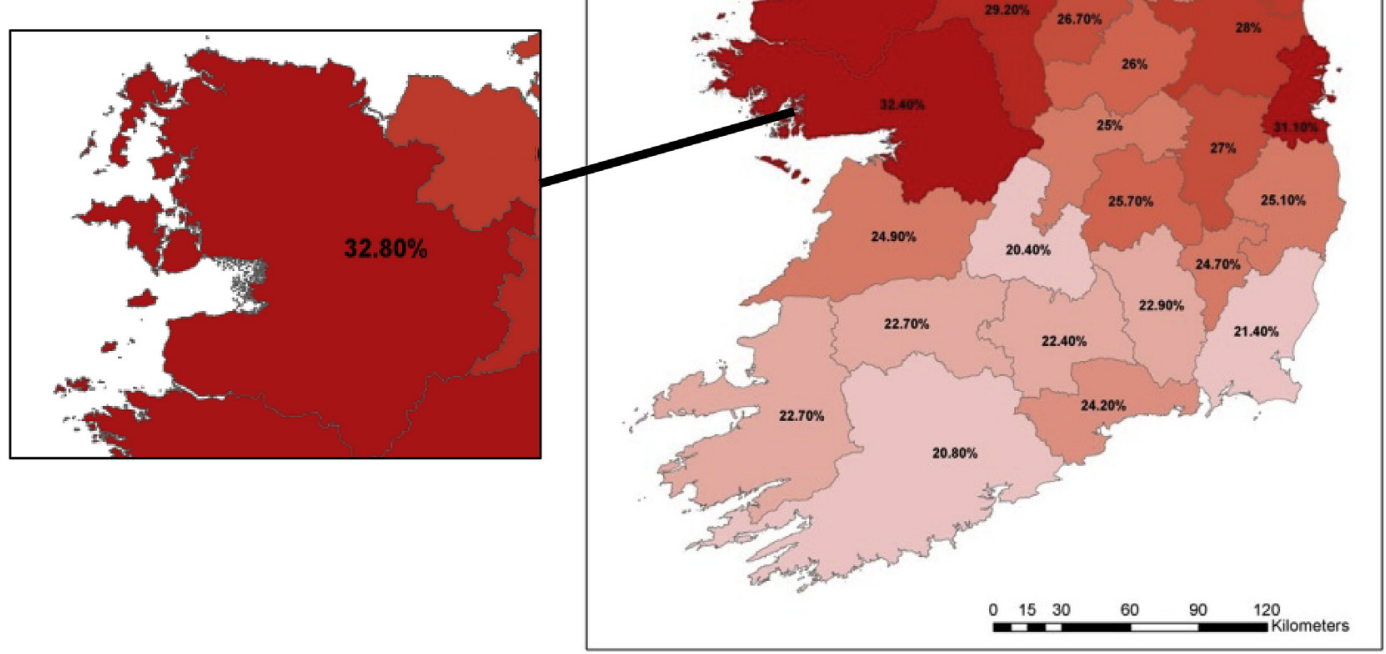

Fig. 1. Farm holders in Ireland aged 65 and older by county (CSO, 2012) 


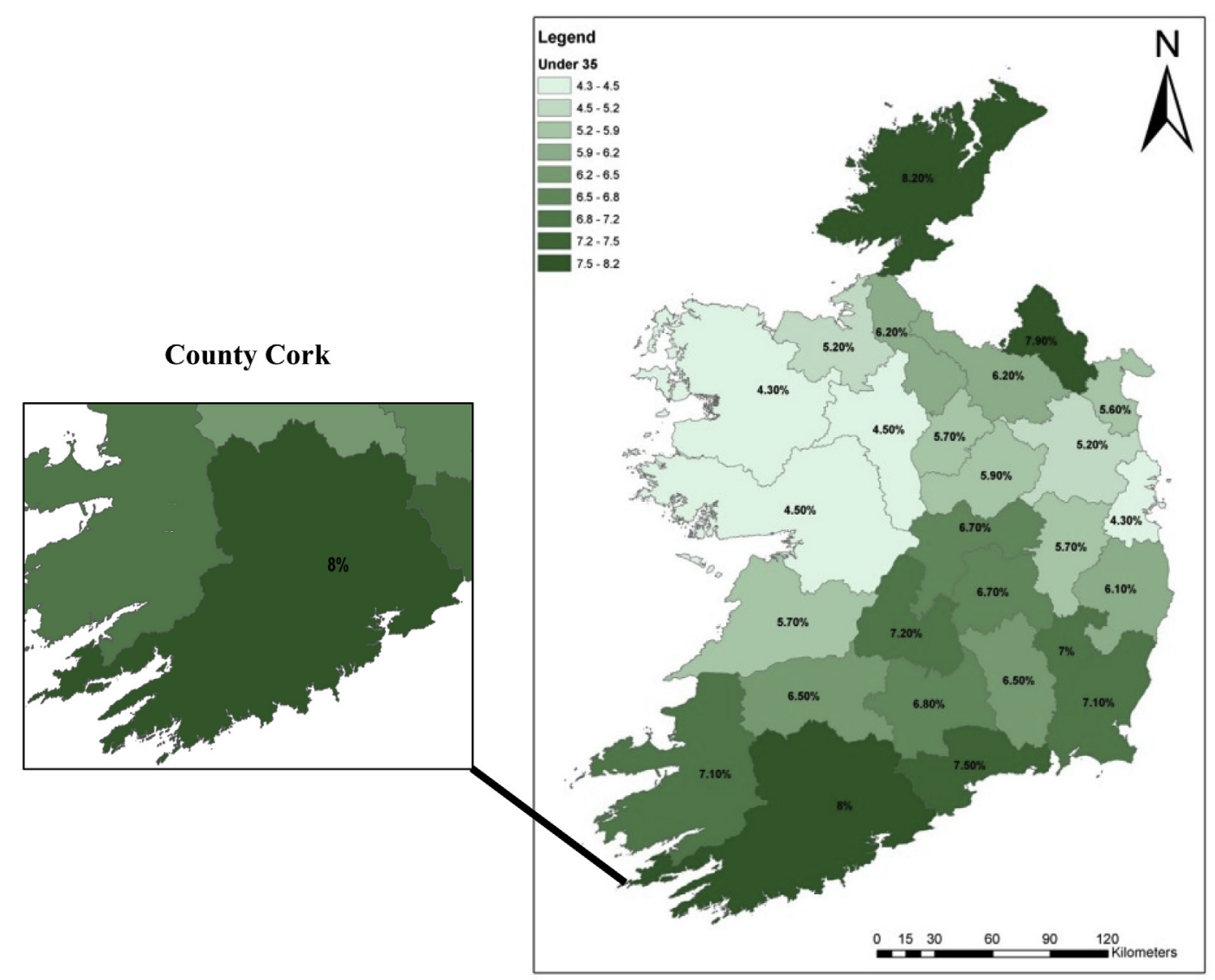

Fig. 2. Farm holders in Ireland under 35 by county (CSO, 2012).

Table 1

Sample farmers.

\begin{tabular}{|c|c|c|c|c|c|}
\hline System & Name & Age & Children & Farm size & Work off farm \\
\hline \multirow[t]{12}{*}{ Beef } & Sean & 61 & 0 & $14 \mathrm{Ha}$ & Retired \\
\hline & Michael & 71 & 4 & $28 \mathrm{Ha}$ & Retired \\
\hline & James & 65 & 3 & $40 \mathrm{Ha}$ & Yes \\
\hline & Richard & 56 & 2 & $19 \mathrm{Hа}$ & Yes \\
\hline & Nora & 80 & 5 & $51 \mathrm{Ha}$ & Retired \\
\hline & Brendan & 65 & 3 & $30 \mathrm{Ha}$ & Retired \\
\hline & Thomas & 61 & 0 & $40 \mathrm{Ha}$ (8 rented) & Retired \\
\hline & Louis & 66 & 2 & $24 \mathrm{Ha}$ & Retired \\
\hline & Jack & 70 & 8 & $30 \mathrm{Ha}$ & Retired \\
\hline & Pat & 58 & 6 & $40 \mathrm{Ha}$ (30 rented) & No \\
\hline & Kevin & 69 & 4 & 58 На (36 rented) & Yes \\
\hline & Stephen & 69 & 2 & $52 \mathrm{Ha}$ & No \\
\hline \multirow[t]{12}{*}{ Dairy } & Joe & 50 & 4 & $40 \mathrm{Ha}$ (12 rented) & No \\
\hline & PJ & 50 & 3 & $100 \mathrm{Ha}$ (60 leased) & No \\
\hline & Enda & 59 & 4 & $36 \mathrm{Ha}$ (57 leased) & No \\
\hline & Donal & 58 & 2 & 36 Ha (15 rented) & No \\
\hline & David & 50 & 4 & $52 \mathrm{Ha}$ (61 rented) & No \\
\hline & Liam & 50 & 4 & 85 На (39 rented) & No \\
\hline & Padraig & 65 & 4 & $40 \mathrm{Ha}$ & No \\
\hline & Peter & 75 & 3 & $40 \mathrm{Ha}$ & No \\
\hline & Mark & 68 & 5 & $40 \mathrm{Ha}$ (28 leased) & No \\
\hline & Luke & 76 & 3 & $85 \mathrm{Ha}$ (40 leased) & No \\
\hline & Paul & 64 & 5 & $45 \mathrm{Ha}$ & No \\
\hline & Damien & 58 & 3 & $26 \mathrm{Ha}$ owned (35 leased) & No \\
\hline
\end{tabular}

farm transfer. The thematic interview captured opinions on key issues including the effect of the farm system on their succession/inheritance decisions, the means by which information was sourced, and also the perception of policy surrounding generational renewal. During the open narrative stage farmers were asked to speak about their own situation and the individuals and circumstances that influence their farm decisions. Any specific themes that did not arise in the narrative but had been identified as integral to the investigation were raised with the interviewee. As opposed to conducting a short questionnaire at the beginning of the interview as suggested by Witzel (2000), this was held until the interview was over in a bid to avoid creating a formal environment that may have resulted in closed or short answers. Similarly, Flick (2014) suggests that a questionnaire at the outset could impede the open nature of the interview before it begins.

\subsection{Qualitative data analysis}

The interviews were conducted on farm and generally lasted between one to $2 \mathrm{~h}$. The research was carried out between the months of January and March of 2018. Before each interview farmers signed a consent form detailing the purpose of the interviews and also noted they would remain anonymous. Interviews were transcribed once complete. Following this the transcripts were printed and key statements regarding finances or forms of risk were highlighted. These statements revealed a range of commonalities across the interviews. The use of manual data analysis in the first instance facilitated a deeper understanding of the data which may not have been the case should a form of analysis software have been employed. Boyatzis (1998) asserts that working with data in this way 'enhances appreciation' (p. 30) of the information gathered and avoids any oversights such as nuances not being detected by software. A second stage of analysis was then undertaken in which the statements were pasted into Excel and placed into sub themes which formed the final (and most prominent) themes or codes. Thematic analysis was used to extract key issues that came to light based on financial concerns and location/farm system. Thematic analysis involves analysing interview transcripts for key themes that appear in a recurring manner as was the case here (Bryman, 2008). Mabry (2008) describe thematic analysis as 'the identification of 


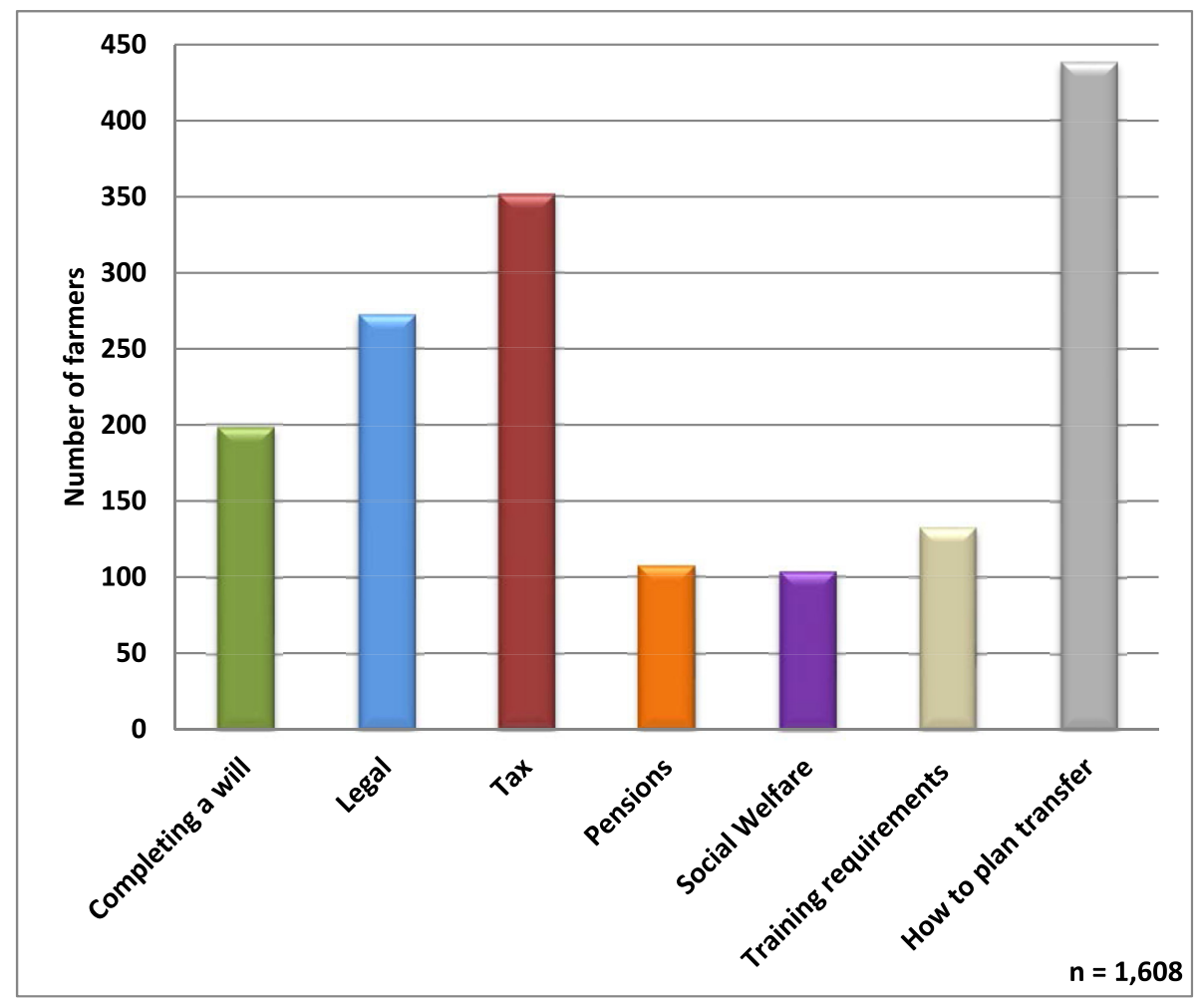

Fig. 3. Main information sought by farmers attending TFFCs.

Source: Leonard et al. (2017a).

emerging patterns and categories from iterative reviews of the dataset' (p. 219). During the analysis of this research several articulations of risk were identified which were used as the basis for coding and organising the analysis of responses. The main themes that emerged were: tax, retirement income, cost of long term care, and marital breakdown.

\section{Risks and uncertainties perceived in the farm transfer}

The following sections outline the key concerns farmers articulated around farm succession and inheritance. The interviews revealed numerous factors of an economic nature that influenced the farmer decision-making process, with varying degrees of negative or positive perception based on the region and farm system in question. A key tool in analysing the interviews was the social constructivist lens which framed all of the articulations of risk in terms of the societal context in which the interviewee was based. Some aspects discussed by farmers had a clear element of measurability (e.g. taxation) while others were immeasurable (e.g. whether or not their successor would experience marital problems), indicating a mix of risks and uncertainties. Here, interviewees from the West are referred to collectively as beef farmers, with those from the South referred to as dairy farmers.

\subsection{Tax as a sensationalised risk}

Despite recent research indicating that land transfer taxation would be of little consequence to an average farmer where his or her successor met tax relief criteria (holding a minimum level of agricultural education etc.) (Leonard et al., 2017b), one of the most prominent concerns that beef farmers had relating to farm succession and inheritance was land transfer taxation. In stark contrast a majority of the dairy farmers saw taxation as something that could be managed efficiently. These concerns were presented mainly by beef farmers in terms of the negative economic effect that a large tax bill would have on a successor. Some interviewees were aware that they could avoid paying Capital Gains Tax (CGT) if the farm was not transferred until after their death, implying however that the financial risk would be dealt with by deferring succession. Michael (71, beef) articulated the concerns of many beef farmers interviewed:

'I hear a lot of people talk about stamp duty, no not stamp duty, eh... inheritance tax. There should be an awful lot more done with that, that you could give it (land) more freely and nobody is crucified. I hear a lot of people say there's places sold over it'.

However, Richard (56, beef) also highlighted his concerns around taxation for both him and his successor:

'If I was to transfer to my sons, the thing that would worry me is what tax implications would be for them. That'd be one of the things that'd concern me. Naturally enough I'd be wondering about my own income'.

Neither of the farmers cited above (like many others) mentioned having availed of any professional consultation to assess possible tax outcomes despite being given the opportunity to comment on same. The implication here is that these and other farmers have built their opinions of land taxation on anecdotal evidence rather than on the advice of taxation or other farm finance professionals, leading to a sensationalised perception of possible consequences (Leonard et al., 2017a). In one instance a beef farmer (Stephen, 69) highlighted that he did not possess sufficient knowledge to make a decision on farm transfer:

'You'd need to know the tax implications of it (land transfer), in other words we don't know enough about the tax implications to make any decision....they'd need to be educated more [i.e. farmers]'.

This comment indicated an awareness of a lack of professional contact; however, given Stephen's age (69) he had chosen to avoid the transfer process thus far despite being aware that he required information prior to making a decision. In a series of surveys conducted by Teagasc with farmers at Teagasc 'Transferring the Family Farm Clinics' (TFFCs) held around Ireland during 2015/16 it emerged that taxation 
was a key reason for their attendance, indicating a high level of uncertainty about its implications for farm transfer (see Fig. 3). Notably, fewer farmers in the South indicated that tax was a prominent reason for their attendance.

As discussed, risk and uncertainty differ in terms of impacts on decision-making. Taxation can be seen as a risk by definition i.e. a calculable outcome (Just, 2001). The beef farmers revealed a high risk perception associated with land transfer tax, but very little engagement with experts who could assess that risk (except for one farmer, who made contact at a late stage), for example accountants or tax advisors. In other words, whilst significant uncertainty was present (and was contributing to a misleading and negative perception of the risk), there was little evidence that this was an issue that required any urgent clarification via other sources of information. Contrary to this, dairy farmers frequently alluded to engaging with professionals (accountants in particular) regarding their family farm transfer, which in turn resulted in a very low risk perception associated with the cost of transferring the farm to their successor. This relates to the connection between adaptation and mitigation (Smit and Skinner, 2002) and risk; engaging with professionals in a timely manner meant that these farmers could adapt to or mitigate against taxation before it became an issue.

The differing views of farmers regarding taxation were evidently a result of an array of phenomena influencing their perceptions of the financial risk it entailed. The risk was that they, or their successor, would have to pay a significant tax bill once the farm was transferred. For dairy farmers interviewed the lower perception of risk around tax stemmed from two main sources; previous experience, and contact with a professional. Donal (58, dairy) briefly summarised the sentiments of many of the farmers regarding taxation:

'We'd expect our accountants will come up with a package that will

be most beneficial to us...you really need people that know what they're doing and do a lot of this'.

Similarly, Padraig (65, dairy) had investigated and was aware of the tax reliefs available for transfer of land to younger farmers:

'We've looked at it a small bit...3 million[euro] is it, tax free transfer? We'd be under that category. It shouldn't be a major issue; it would have to be done before (son) is 35'.

Dairy farmers in general exhibited a more comprehensive knowledge of structures and reliefs associated with land transfer tax, and this evidently contributed to a positive approach to farm transfer. The value of an average dairy farm is generally higher than that of their beef counterparts, meaning dairy farmers would have higher land transfer taxation bills (if any). As noted, the level of income accrued by dairy farmers tends to be higher, this in turn relates to the frequency of which dairy farmers engage with professionals (such as accountants). Thus directly linking dairy farmers with a regular source of knowledge with regard to land transfer contributing to a lower risk perception.

In addition to contact with professionals, some dairy farmers referred to their own experience of receiving the family farm. Joe (50, dairy) for example noted that he paid 'very minor tax for inheritance' when he had taken over the family farm. The experience provided by Joe reinforces the opinion of Klinke and Renn (2002) who assert that familiarity or association with a risk can dictate an individual's perception. In this instance dairy farmers exhibited a low level risk perception, stemming from a clear knowledge of the risk (i.e. lower uncertainty about it), and in some cases previous positive association with farm transfer.

Evidently there is a heightened perception of risk associated with land transfer taxation for beef farmers in the West of Ireland, whilst those involved in dairying in the South exhibit a more open and positive approach to taxation. This variance in perception resonates with the notion that risk is contextual (Birkholz et al., 2014). i.e. risk perceptions are created by numerous factors that are specific to a particular social context. While all interviewees were situated within the same policy environment, they were embedded in distinctly contrasting discourses. Of particular note were the economic differences within the sample which appeared to be strongly correlated with farm system and region.

\subsection{Retirement income}

Although the factors affecting farm transfer decisions are influenced to some degree by the cultural and social contexts in which the farmer operates (including for instance distinctive and often localised farming cultures, farmers' peer groups, and relationships with state-sponsored and private advisory staff and other consultants and experts), the economic context is arguably the most important for the majority of farmers (Whitehead et al., 2012; Rossier, 2012).

Given the intricate linkage between farm succession/inheritance and retirement many interviewees alluded to concerns about sources of retirement income. While most farmers may never actually retire in the sense of remaining active in the farm operations, what is meant by retirement income for this research is the available income once the farm has been transferred to a successor. As with taxation issues, there were contrasting views between higher income farmers in dairying and lower income farmers in beef. However, both raised concerns regarding a need for economic security once they transferred the farm, indicating economic risk linked to farm exit. Leonard et al. (2017c) raise concerns that if farmers become purely dependant on an Irish state pension (contributory) once the farm has been transferred, this would not provide a substantial income (less than $€ 21,000$ annually between a farmer and their spouse). In his 2013 report on Irish farm succession, Bogue (2013) found that $82 \%$ of farmers surveyed (197 of 421 surveyed answered this question) would be dependent on such a pension once their successor had taken over the farm.

Sean (61, beef) voiced these concerns, stating that he would be in a vulnerable position once the farm was signed over, noting a fear of being forced out of his home:

'It's very hard for them [farmers] to hand over all their assets, and basically you're 70 or 80 years of age and you now have nothing, or that's the way you think -I've given away everything', it feels like. If they throw me out on the side of the road that's where I'm going to be; there has to be something to encourage us to sign over'.

This illustrates a strong linkage between farm transfer and fear of being economically dependant on others once the transfer process was completed. For Sean a lack of security in one's own home was one of the key economic factors hindering his engagement with the process of transferring the farm to his nephew. Lobley et al. (2010) concur with these concerns surrounding retirement income noting that 'inadequacy of pension provision' (p.61) can act as a barrier to farmer engagement with retirement or semi-retirement processes. Thomas (beef, 61) alluded to the inadequacy of a pension provision, but also the shortcoming in government policy to support exiting farmers:

'I think since they got rid of this European pension scheme it has affected the whole scheme quite a bit, at least you had some security then when that was in it, guaranteed something like. If you're depending on just the state pension it's very little really'.

Thomas' comments express the need for security once the farm has been handed over, implying that this would reduce the economic risk of not having enough income once retired. Koundouri et al. (2009) assert that financially incentivised schemes can contribute to a reduction in financial risk for farmers. Echoing this, Vollenweider et al. (2011) contend that agri-environmental payments may be seen as a means of income stabilisation for some farmers. Without the presence of income stabilisation supports beyond farm exit or semi-retirement farmers may continue to avoid the farm transfer process, because depending on a low income farm to support two generations is unfeasible. In the context of New Zealand agriculture, McLeod (2012) asserts that 
dependence on the business for a basic income and the fear of losing this is 'possibly one of the main reasons that owners fear the process so much' (p. 187). Similarly, Errington (2002) found that English farmers continued to rely on the farm for income even past retirement age, with many farmers protecting their 'pension' (i.e. the farm) by retaining managerial control as they got older. In this way, farmers ensure they are not facing the risk of having little or no income later in life.

While dairy farmers discussed prospective retirement income sources they did not indicate a lack of income as a risk, but postulated that they would need to prepare for later life by means of a private pension. A private pension plan depends on the retiree's ability to pay into such a fund during their working life, and for the dairy farmers interviewed this was less of an issue. Joe (dairy, 50) outlined his plan to use farm income to build a pension on which to live on once he had transferred the farm:

'By the time I'm 60 we would be in a partnership; he [his son] would be doing most of the work, drawing an income from it. Then in a few years I'd have enough set aside that I could retire...if I can make enough in the next 10 years to secure myself for retirement'.

In the same way, PJ (dairy, 50) described how current farm income would be used to fund a pension that would ensure financial stability once one of his daughters took on the farm:

'I would be hoping that I'd have the majority of my income in a pension of some description... you don't need a huge income when you retire but you need an income, you need a recurring income that's safe'.

At present there is no form of farm retirement scheme or farmer's pension in Ireland, apart from the already-mentioned state pension that is available to citizens from the age of 66. In Switzerland, farmers receive 'old age survivor's insurance' provided they have handed over the farm to a successor by the age of 65 . As is the case in Ireland, there is a high reliance in Switzerland on direct farm payments, meaning that this relatively reliable source of farm income becomes a disincentive to farm transfer (Rossier, 2012). Similarly in Germany, farmers receive a pension once they have transferred the farm and relinquished their farm income (Mehl, 2009). Based on the empirical results from this research, farmers would welcome a form of income security once they reach an age at which they could semi-retire. Policies based on the transfer of all assets however, or an implication in such an arrangement that farmers would fully exit farming may result in low uptake from farmers, as indicated in the findings of Conway et al. (2017).

\subsection{Long term care costs}

When discussing farm succession and inheritance many farmers raised concerns around their own ageing and the possibility of longterm care costs to be faced. While costs of long term care are clearly linked to retirement income, this emerged as a strong theme and thus merited discussion separate to that of retirement income. This issue was raised as a significant risk by beef and dairy farmers alike. Internationally, farm successors are subject to different arrangements regarding care for their parents once they take on the farm. In Israel, only one successor can be chosen, and the successor is the only child to build a home on the family plot of land; legal transfer of farm assets takes place later in life with an obligation on the successor to care for their elderly parents (Kimhi and Nachlieli, 2001). Likewise, successors in Austria care for their parents later in life as opposed to buying the farm from them (Stiglbaeur and Weiss, 1999). In the case of this research many farmers implied that their successor would assist in caring for them later in life but were acutely aware that the cost of going to a nursing home would be high should they have to do so. Donal (58, dairy) had strong concerns that there would be serious economic issues if the farm had to fund him staying in a nursing home. While he did not explicitly make a connection between this and a heightened risk of transferring the farm, this was one obvious implication; if he transferred the farm, he would possibly not have an independent means to pay for care. The other risk was that by placing the burden on the successor (should he go ahead with farm transfer) it would financially threaten the farm's viability:

'The other thing that's coming down the road here is the cost of healthcare, and as you get older the cost of a nursing home is $€ 1,000$ a week...there aren't many farming businesses that can support that....that definitely is always in the back of your head when you're moving forward'.

Of note here is the fact that Donal is involved in one of the most profitable farm systems but still feels that the cost of long-term care could threaten the farm financially. Marsden et al. (1992) assert that finances associated with providing for care of an elderly farmer can lead to 'severe drain on capital resources' (p. 419). While the Nursing Home Support Scheme (NHSS - also known as the Fair Deal Scheme ${ }^{2}$ ) aims to assist with the cost of long term care, farmers are in the unique position of owning substantial assets that may be taken into account as part of a means test to qualify for the scheme. For the farm to be excluded from the means test, farmers must have transferred all farm assets 5 years prior to entering long term care. Recent changes made to the scheme have improved the position of farmers, in that farms are included in the means test, but only for the first 3 years which a person is in care. Michael (71, beef) had strong reservations about the NHSS:

'I think the older people that made this country the way it is, they're not being looked after right, even just to give them a decent place in a home, they're crucified now to go into a home, god forbid if I had to go in. The place would be sold over it, that fair deal scheme, it's not a fair deal. It's like a lot of the other schemes, it's only meant for a few'

Michael's concerns were centred on the potential loss of the farm due to the financial pressures placed on the business as a result of the NHSS conditions. While this issue of care potentially surfaces whether or not the farm has been transferred, the main point for this discussion is that it does feature as one of the considerations that (indirectly at least) is influencing the overall risk assessment for farm transfer, i.e. it introduces further uncertainty to the decision-making process.

\subsection{Concerns around marriage breakdown}

In most instances, themes that emerged from this research were common to both farm systems; however, breakdown of a successor's marriage only appeared as a key concern for dairy farmers, because of the potential loss of the farm through subsequent division of assets. Notably, there was no question in the interview guide that related to this topic yet many farmers highlighted it as an issue. These concerns were centred on the risk not only of losing an asset laden with personal value, but also an economic asset. In this research, marriage was seen as a barrier to farm transfer rather than a pivotal moment that encouraged a farmer to engage in the process, in other words, it is construed as a risk which may in certain circumstances constitute a reason to defer farm transfer. Mark (68, dairy) articulated serious concerns around a marriage breakdown resulting in the farm being sold:

'The real fear farmers have in the back of their minds is in case the farm won't be secure going forward, especially now with family break ups and things, this is the real fear people have. If you transfer

\footnotetext{
${ }^{2}$ The NHSS is a scheme of financial support for people who need long-term nursing home care. Under the NHSS, those who require long term care contribute towards the cost of care required and the state contributes the rest of the cost based on a financial assessment which takes into account assets owned, including farm assets (https://www2.hse.ie/file-library/fair-deal/fair-dealinformation-booklet.pdf) (Health Service Executive, 2017).
} 
the land to your son and your son gets married and the marriage breaks up, the farm has to be sold, that's the real fear'.

This comment summarises the concerns raised by several dairy farmers interviewed, and also resonates with research findings in international contexts. The possibility of divorce is cited among the reasons for late transfer in Australia with Barclay et al. (2012), outlining the concerns of farmers about successors' marriage break-up and divorce resulting in the sale of the family farm. In a similar manner, Fischer and Burton (2014) assert that the timing of a farm transfer depends on many factors, but of particular importance is when a young farmer marries and to whom. Donal (58, dairy) was of the opinion that this would not be an issue for his farm based on confidence in professionals associated with such legalities:

'The stories you hear are of whoever has taken over the farm, their marriage breaking up, there will be I presume steps taken to protect the business'.

In this instance, Donal was implying that a form of mitigation may include the use of a prenuptial agreement to protect farm assets; however, Price and Evans (2006) who write about the issue of marriage break up and the fate of family farms contend that these agreements tend to have little legal standing. In their research, interviewees solely discussed the possibility of women being a threat to the farm 'by virtue of their entitlements if the relationship breaks down' (p. 280). These concerns may not necessarily be rooted in a mistrust of a successor's partner (or their gender), but more linked to the uncertainty associated with an external individual becoming embedded in the farm enterprise, which is intrinsically linked to the risk of having to sell the family farm. However, in this research, concerns about female heirs was also raised. PJ (50, dairy) who only has daughters was clear on the fact that their partners would influence his decision on farm transfer:

'It depends on who my daughters team up with; who they pick as partners has a huge influence on it'.

Additionally, a lack of any form of mitigation against the possible eventuality of the farm being sold means that farmers have no control over the situation, which only servers to heighten negative perceptions of the farm transfer process. In the absence of a means by which to protect the farm, farmers will continue to avoid engaging in farm transfer as a result of the uncertainty present and the perception of risk that it constitutes.

\section{Discussion}

This paper has set out to understand the importance of economic and financial factors in farm transfer decisions. It has done this through examining farmers' socially-constructed risks about the economic viability of their farms and the effects of uncertainty as they arise from key unexpected events (that also have significant economic implications for the farm), and how these impact upon farmers' decision-making for succession planning. Approaching risk as a socially-constructed phenomenon has provided unique insights into some of the complexities of economic and financial decision-making on farm succession at the level of the individual farmer. These are issues that farmers in this research believed are not always sufficiently accommodated under the available, but more rigid approaches to state generational renewal policy which do provide for a clearly calculable risk (e.g. taxation), and/or arise from other uncertainties about income security and the longer-term security of the farm holding post-transfer (e.g. the possible need for long-term care, or successor's marriage breakdown). These constituted the two key, reiterated concerns of farmers: first, the need for financial security once a farmer reached retirement age; second, the possibility of having to sell the farm to release finance as a direct result of unanticipated events like illness or divorce.

The financial implication of a process that is also influenced by social considerations is clearly evidenced in this research. These dilemmas are already reflected to some extent in the work of Ward and Lowe (1994) in their references to farm succession as a 'social goal' (p.175) that nonetheless is heavily contextualised within financial and legal considerations, which (in the case of this research) ultimately drive the decision-making process. However, the means to take account of these complex realities and subsequent approaches to risk-construction and decision-making are not currently available in policy, and thus create difficulties for key institutional stakeholders (e.g. advisory services) who have a strong vested interest in promoting farm transfer for farm and wider agricultural sector efficiency reasons, but who have limited scope to discuss satisfactory options with potential farm retirees.

The clear divide in understandings on the implications of taxation was evident between the beef and dairy farmers, with the larger and more financially profitable dairy farms (all farmers including prospective successors as full-time farmers) evidently having a succession plan in place. These farmers reported being in regular contact with their accountants and thus had a low risk perception regarding land transfer taxation. The beef farmers on the other hand who were all part-time farmers were far less aware of the taxation implications and were working on the basis of anecdotal information about taxation obligations, constructing same into a negative risk perception (Klinke and Renn, 2002). The hosting of advice clinics by Teagasc around the country in 2015 saw over 1600 farmers attending, reflecting a desire for information on farm succession options and implying a prevailing and significant level of uncertainty. Based on dairy farmers' practices, i.e. their more sustained, one-to-one engagement with their accountants or the relevant experts (which clearly reduces levels of uncertainty and builds the perception of farm transfer as a manageable risk), it would appear that in order to change risk perceptions for other groups of farmers, some form of individualised advisory service would be needed. The need to counteract anecdotal but possibly erroneous accounts of successors being faced with financially ruinous tax bills (i.e. a sensationalised risk, as discussed by Klinke and Renn, 2002) through making more accurate information available to farmers on the financial implications associated with farm transfer would seem to be a priority response by the relevant institutional actors. With the correct information and professional assistance, farmers can act to mitigate or eliminate some of the risks they perceive. A continuation of the Teagasc Transferring the Family Farm Clinics, ${ }^{3}$ with an emphasis on one-to-one consultations, would assist in providing farmers who generally do not have a high level of contact with professionals with the information they need to prepare in a timely manner for eventual farm transfer, taking into account the potential complexities of each individual case and the reality that risk is contextual (Veerman et al., 2016; Birkholz et al., 2014).

In the context of an ageing society the concerns raised regarding the inadequacy of the state pension system go beyond the farming community, posing serious questions as to how policy can support an evergrowing older population. With regard to older persons in rural areas, specifically those who are members of the farming community, there is strong merit in considering more support for Home Help ${ }^{4}$ initiatives as a means of avoiding entering long term care and placing a strong economic burden on farm families. Where long term care in the form of a nursing home is required, the stipulations of the NHSS should be reviewed so that a means test would reflect the actual income accrued from a farm as opposed to the value of the assets should they be sold. In

\footnotetext{
${ }^{3}$ These events allow farmers to meet with professionals (accountants, solicitors etc.) free of charge and are facilitated by Teagasc.

${ }^{4}$ The home help service provides support to people in the community who need help with day-to-day tasks because of illness or disability. http://www. citizensinformation.ie/en/health/health_services/care_in_your_community/ home_helps.html (Citizens Information, 2017).
} 
most cases the farm income does not equate to the farm value, in particular for lower income farm systems such as beef and sheep farming.

Given the widespread concern amongst dairy farmers in relation to successor marital breakdown, a case is to be made for reconsidering the current legalities associated with prenuptial agreements. Prior to this however, further research into legal structures surrounding marriage breakdown in farm situations is required.

Alleviating the risk of economic insecurity once a farmer has reached an age at which they wish to transfer the farm may take the form of a farmer's pension or a more farmer friendly retirement scheme. Based on the results of this research, farmers would be more open to earlier farm transfer if they were not facing economic risk once the process was complete. However, the succession and inheritance process affects both a farmer and their successor, thus a scheme which encourages both parties to engage would have more relevance. For example a 'Farm Future' programme which would require farmers to have a plan in place over a number of years in order to receive a gradual exit payment which increased as the transfer of assets came closer would be an example of such a scheme. This would involve the requirement of a farm transfer plan to be in place on joining the scheme; the plan could take a similar time scale to the Succession Farm Partnership Scheme which allows for a transfer over a period of up to 10 years. In addition, the Farm Future programme could allow for retention of $20 \%$ of farm assets for the older farmer should the wish. The gradual payment would change based on transfer of ownership i.e. if a farmer had transferred $50 \%$ of the farm assets, they would receive $50 \%$ of the maximum payment amount. In this way, the transfer is not sudden, and the farmer will be aware of the financial situation going forward, reducing risk perception.

Another possible option would be to provide a supplementary payment to farmers who are eligible for a state pension should they commit to farm transfer, again, the benefit of such a payment would be that farmers have a degree of certainty in economic terms once they have transferred the farm to a successor. One key stipulation for this state pension top up would be that the recipient cannot also have a private pension fund, in this way; the payment would target lower income farmers who are unable to contribute to a private pension. In addition, it is evident from the results attained here that those who have private pensions do not perceive this aspect of farm transfer as a risk that would negatively impact their decision to transfer. For those who are eligible, such a payment would decrease the risk perception linked to concerns around income once the family farm has been transferred. The available evidence is that there is scope for innovation in this regard, with the earlier examples cited from Switzerland, and Germany (Mehl, 2009) providing secure options for both farmers and their successors post-farm transfer. Under current arrangements, the prospects for any dramatic improvement in the rate of farm transfer do not appear imminent.

\section{Conclusion}

The research focused on the influence of economic aspects of farm succession and inheritance on farmer decision making resulting in a range of implications for policy and practice. A clear policy focus on the entry of younger farmers amplifies the neglect of older farmers and the provision of a viable means for them to begin the process of gradual farm exit. While it was evident that policy alone does not act as a sole driver of the farm transfer choices farmers make, it does make a strong contribution to the perceptions farmers have of their retirement options. This related to the social construction of the range of succession and inheritance risks/uncertainties that are influenced by the societal spheres and networks in which farmers operate.

The broad implication arising from this research is that farmers do perceive some economic aspects of farm succession, inheritance and retirement as a risk (or uncertainty in some cases); whilst current policy makes insufficient effort to aid the reduction of this perceived risk. The influence of monetary facets of farm transfer is pervasive, but should not be considered in isolation, therein lies the benefit of viewing the perceptions of farmers as socially constructed. Efforts on behalf of policy makers to encourage generational renewal in agriculture should thus be cognisant of the complex decision making deductions that farmers part take in, but also the very clear differences that exist between farm income levels as a result of farm systems. Prescribing a blanket policy to such an idiosyncratic group will only lead to a sustained increase in the number of older farm operators, leading to negative implications for the agricultural sector and young farmers waiting to gain entry.

\section{CRediT authorship contribution statement}

Brian Leonard: Conceptualization, Methodology, Formal analysis, Investigation, Data curation, Writing - original draft, Writing - review \& editing. Maura Farrell: Conceptualization, Methodology, Writing review \& editing, Resources, Supervision, Project administration, Funding acquisition. Marie Mahon: Conceptualization, Methodology, Writing - review \& editing, Resources, Supervision, Project administration, Funding acquisition. Anne Kinsella: Conceptualization, Methodology, Writing - review \& editing, Resources, Supervision, Project administration, Funding acquisition. Cathal O'Donoghue: Writing - review \& editing, Resources, Supervision, Project administration, Funding acquisition.

\section{Acknowledgements}

The authors are grateful to the Royal Dublin Society and the Teagasc Walsh Fellowship Programme for funding this research. In addition to this the authors would like to thank the farmers who participated in the research.

\section{References}

Adams, J., 1995. Risk. University College London Press, London, UK.

Barclay, E., Reeve, I., Foskey, R., 2012. Australian farmers' attitudes toward succession and inheritance. In: Lobley, M., Baker, J.R. (Eds.), Whitehead, I. 2012. 'Keeping it in the Family'. Ashgate Publishing Limited, Surrey, pp. 21-35.

Barlett, P.F., 1980. Introduction: development issues and economic anthropology. In: Barlett, P.F. (Ed.), 1980. Agricultural Decision Making: Anthropological Contributions to Rural Development. Academic Press, New York.

Beck, U., 1992. Risk Society: towards a New Modernity, vol. 17 Sage, London.

Bertoni, D., Cavicchioli, D., 2016. Process description, qualitative analysis and causal relationships in farm succession. CAB Reviews 11 (43), 1-11.

Birkholz, S., Muro, M., Jeffrey, P., Smith, H.M., 2014. Rethinking the relationship between flood risk perception and flood management. Sci. Total Environ. 478, 12-20.

Bogue, P., 2013. Land Mobility and Succession in Ireland, Report Prepared for Macra Na Feirme.

Botzen, W.J.W., Aerts, J.C.J.H., Van Den Bergh, J.C.J.M., 2009. Dependence of flood risk perceptions on socioeconomic and objective risk factors. Water Resour. Res. 45 (10), $1-15$.

Boyatzis, R.E., 1998. Transforming Qualitative Information: Thematic Analysis and Code Development. Sage, London.

Breustedt, G., Glauben, T., 2007. Driving forces behind exiting from farming in western europe. J. Agric. Econ. 58 (1), 115-127.

Bryman, A., 2008. Social Research Methods, third ed. Oxford University Press, Oxford.

Buckwell, E.A., Matthews, A., Baldock, D., Mathijs, E., 2017. CAP - Thinking Out of the Box: Further Modernisation of the CAP - Why, what and How? RISE Foundation, Brussels.

Calus, M., Huylenbroeck, Van, Van Lierde, D., 2008. The relationship between farm succession and farm assets on Belgian farms. Sociol. Rural. 48 (1), 38-56.

Caskie, P., Davis, J., Campbell, D., Wallace, M., 2002. An Economic Study of Farmer Early Retirement and New Entrant Schemes for Northern Ireland. Queen's University Belfast.

Cavicchioli, D., Bertoni, D., Pretolani, R., 2018. Farm succession at a crossroads: the interaction among farm characteristics, labour market conditions, and gender and birth order effects. J. Rural Stud. 61, 73-83.

Central Statistics Office, 2012. 'Census of Agriculture 2010 - Final Results'. Government of Ireland, Cork.

Chang, H., 2013. Old farmer pension program and farm succession: evidence from a population-based survey of farm households in Taiwan. Am. J. Agric. Econ. 95 (4), 976-991. https://doi.org/10.1093/ajae/aat004.

Citizens Information, 2017. Home help service. Available from:, 13th November 2018. 
http://www.citizensinformation.ie/en/health/health_services/care_in_your community/home helps.html.

Centre for Integrated Agricultural Systems (CIAS), 1996. New Zealand's Dairy Career Path: Evaluating a Farm Entry/exit Strategy. Research Brief \#34, Available at: http://www.cias.wisc.edu/sharemilking-in-wisconsin-evaluating-a-farm-entryexitstrategy/ 27/03/15

Clarke, L., Short, J.F., 1993. Social Organisation and Risk: some current controversies. Annu. Rev. Sociol. 19, 375-399.

Contzen, S., Zbinden, K., Neuenschwander, C., Métrailler, M., 2017. Retirement as a discrete life-stage of farming men and women's biography? Sociol. Rural. 57 (1), 730-751.

Conway, S.F., McDonagh, J., Farrell, M., Kinsella, A., 2016. Cease agricultural activity forever? Underestimating the importance of symbolic capital. J. Rural Stud. 44, 164-176.

Conway, S.F., McDonagh, J., Farrell, M., Kinsella, A., 2017. Uncovering obstacles: the exercise of symbolic power in the complex arena of intergenerational farm transfer. J. Rural Stud. 54, 60-75.

Davis, J., Caskie, P., Wallace, M., 2009. Economics of farmer early retirement policy. Appl. Econ. 41 (1), 35-43.

De Haan, H., 1994. In the Shadow of the Tree: Kinship, Property and Inheritance Among Farm Families. Het Spinhuis, Amsterdam.

Dillon, E., Moran, B., Donnellan, T., 2017. Teagasc National Farm Survey 2016, Rural Economy and Development Programme. Teagasc.

Dillon, E., Moran, B., Lennon, J., Donnellan, T., 2018. Teagasc National Farm Survey 2017, Rural Economy and Development Programme. Teagasc.

Downey, H., Threlkeld, G., Warburton, J., 2017. What is the role of place identity in older farming couples' retirement considerations? J. Rural Stud. 50, 1-11.

Errington, A., 2002. Handing over the reins: a comparative study of intergenerational farm transfers in England, France and Canada. In: Xth EAAE Congress, Zaragoza, Spain, 28 - 31 August 2002.

File, K.M., Prince, R.A., 1996. Attributions for family business failure: the heir's perspective. Fam. Bus. Rev. 9 (2), 171-184.

Fischer, H., Burton, R.J., 2014. Understanding farm succession as socially constructed endogenous cycles. Sociol. Rural. 54 (4), 417-438.

Fleisher, B., 1990. Agricultural Risk Management. Lynne Rienner Publishers Inc, Boulder.

Flick, U., 2014. An Introduction to Qualitative Research, fifth ed. Sage, London.

Glauben, T., Tietje, H., Weiss, C.R., 2004. Succession in Agricultural Households: A Probit and a Competing Risk Analysis (No. 0406). FE working paper//University of Kiel, Department of Food Economics and Consumption Studies.

Groom, B., Koundouri, P., Nauges, C., Thomas, A., 2008. The story of the moment: risk averse Cypriot farmers respond to drought management. Appl. Econ. 40 (3), 315-326.

Hardaker, J.B., Lien, G., Anderson, J.R., Hurine, R.B.M., 2015. Coping with Risk in Agriculture: Applied Decision Analysis, third ed. Cabi, Oxfordshire.

Health Service Executive, 2017. Nursing home support scheme information booklet. Available from:, 17th November 2018. https://www2.hse.ie/file-library/fair-deal/ fair-deal-information-booklet.pdf.

Hennessy, T., 2014. CAP 2014 - 2020 Tools to Enhance Family Farming: Opportunities and Limits, Prepared for the European Parliament's Committee on Agriculture and Rural Development.

Hennessy, T., Rehman, T., 2007. An investigation into factors affecting the occupational choices of nominated farm heirs in Ireland. J. Agric. Econ. 58 (1), 61-75.

Hennessy, T., Moran, B., 2016. Teagasc National Farm Survey 2015, Rural Economy and Development Programme. Teagasc.

Howley, P., O'Donoghue, C., Heanue, K., 2012. Factors affecting farmers' adoption of agricultural innovations: a panel data analysis of the use of artificial insemination among dairy farmers in Ireland. J. Agric. Sci. 4 (6), 171-179.

Ingram, J., Kirwan, J., 2011. Matching new entrants and retiring farmers through joint ventures: insights from the Fresh Start Initiative in Cornwall, UK. Land Use Policy 28, 917-927. https://doi.org/10.1016/j.landusepol.2011.04.001.

Just, R.E., 2001. Addressing the changing nature of uncertainty in agriculture. Am. J. Agric. Econ. 83 (5), 1131-1153.

Kaupilla, D., Kinsella, A., Loughrey, J., McDonnell, J., O'Donoghue, C., Thorne, F., 2013. Identifying and managing risks. In: Teagasc Dairy Conference 2013.

Kimhi, A., Nachlieli, N., 2001. Intergenerational succession on Israeli family farms. J. Agric. Econ. 52 (2), 42-58.

Kirby, A. (Ed.), 1990. Nothing to Fear: Risks and Hazards in American Society. University of Arizona Press, Tuscon.

Klinke, A., Renn, O., 2002. A new approach to risk evaluation and management: riskbased, precaution-based, and discourse-based strategies. Risk Anal. 22 (6), 1071-1094.

Koundouri, P., Laukkanen, M., Myyra, S., Nauges, C., 2009. The Effects of EU Agricultural Policy Changes on Farmers' Risk Attitudes. European Review of Agricultural Economics, pp. 1-25.

Leonard, B., Kinsella, A., Phelan, F., 2017a. Transferring the family farm: famer concerns. T Research 12 (1) Spring 2017, Teagasc: Oak Park.

Leonard, B., Kinsella, A., O'Donoghue, C., Farrell, M., Mahon, M., 2017b. Policy drivers of farm succession and inheritance. Land Use Policy 61, 147-159.

Leonard, B., Mahon, M., Kinsella, A., O'Donoghue, C., Farrell, M., Curran, T., Hennessy, T., 2017c. The potential of farm partnerships to facilitate farm succession and inheritance. Int. J. Agric. Manag. 6 (1), 1-16.

Lobley, M., Potter, C., 2004. Agricultural change and restructuring: recent evidence from a survey of agricultural households in England. J. Rural Stud. 20 (4), 499-510. https://doi.org/10.1016/j.jrurstud.2004.07.001.

Lobley, M., Baker, J., 2012. Succession and retirement in family farm businesses. In: Lobley, M., Baker, J.R. (Eds.), Whitehead, I. 2012. Keeping it in the Family. Ashgate
Publishing Limited, Surrey, pp. 1-19.

Lobley, M., Baker, J.R., Whitehead, I., 2010. Farm succession and retirement: some international comparisons. J. Agric. Food Syst. Community Dev. 1 (1), $49-64$.

Mabry, L., 2008. Case study in social research. In: Alasuutari, P., Bickman, L., Brannen, J. (Eds.), 2008. The SAGE Handbook of Social Research Methods. Sage Publications, London.

Macken-Walsh, A., 2010. A Review of the Social Benefits of Joint Farming Ventures. Teagasc Rural Economy Research Centre, Galway.

Marsden, T., Munton, R., Ward, N., 1992. Incorporating social trajectories into uneven agrarian development. Sociol. Rural. 32 (4), 408-430.

Matthews, A., 2014. The agri-food sector. In: O'Hagan, J., Newman, C. (Eds.), 2014. The Economy of Ireland: National and Sectoral Policy Issues, twelfth ed. Gill and Macmillan, Dublin.

Mayo County Council, 2019. A Sustainable Agriculture Strategy for Mayo.

McLeod, M., 2012. Business continuance and succession planning: a New Zealand perspective. In: Lobley, M., Baker, M.J., Whitehead, I. (Eds.), Keeping it in the Family: International Perspectives on Succession and Retirement on Family Farms. Ashgate Publishing, Ltd.

Mehl, P., 2009. A marathon rather than a sprint: the reform of the farmers' pension system in Germany and its impacts. In: Beckmann, V., Padmanabhan, M. (Eds.), 2009. 'Institutions and Sustainability. Springer Science and Business Media, pp. 61-81.

Mills, J., Gaskell, P., Ingram, J., Dwyer, J., Reed, M., Short, C., 2017. Engaging farmers in environmental management through a better understanding of behaviour. Agric. Hum. Val. 34 (2), 283-299.

Mishra, A.K., El-Osta, H.S., 2007. Factors affecting succession decisions in family farm businesses: evidence from a national survey. J. ASFMRA 70 (2007), 1-10.

Mishra, A.K., El-Osta, H.S., Shaik, S., 2010. Succession decisios in U.S. family farm businesses. J. Agric. Resour. Econ. 35 (1), 133-152.

Morris, C., Potter, C., 1995. Recruiting the new conservationists: farmers' adoption of agri-environmental schemes in the UK. J. Rural Stud. 11 (1), 51-63.

National Rural Network (NRN), 2012. Potential of Farm Partnerships to Facilitate Entry into and Establishment in Farming. report prepared by Dr. Pat Bogue for the National Rural Network).

O'Connor, D., Keane, M., 2014. Future Expansion of the Dairy Industry in Cork: Economic Benefits and Infrastructural Requirements. Report prepared for Cork County Council (December).

O'Connor, D., Renting, H., Gorman, Kinsella, J., 2006. The evolution of rural development in europe and the role of EU policy. In: O'Connor, D., Renting, H., Gorman, Kinsella, J. (Eds.), Driving Rural Development: Policy and Practice in Seven EU Countries. van Gorucm, Assen, pp. 1-17.

Pieczka, M., Escobar, O., 2012. Dialogue and Science: innovation in policy-making and the discourse of public engagement in the UK. Sci. Public Policy 40 (1), 113-126.

Potter, C., Lobley, M., 1996. Unbroken threads? Succession and its effects on family farms in britain. Sociol. Rural. 36 (3), 286-306. https://doi.org/10.1111/j.1467-9523. 1996.tb00023.x.

Price, L., Evans, N., 2006. From 'as good as gold' to 'gold diggers': farming women and the survival of British family farming. Sociol. Rural. 46 (4), 280-298.

Rossier, R., 2012. Farm succession in Switzerland: from generation to generation. In: Lobley, M., Baker, M.J., Whitehead, I. (Eds.), Keeping it in the Family: International Perspectives on Succession and Retirement on Family Farms. Ashgate Publishing, Ltd.

Rovny, P., 2016. The analysis of farm population with respect to young farmers in the European Union. Procedia - Social and Behavioural Sciences 220, 391-398.

Scolobig, A., De Marchi, B., Borga, M., 2012. The missing link between flood risk awareness and preparedness. Findings from case studies in an Italian Alpine Region. Nat. Hazards 63 (2), 499-520. https://doi.org/10.1007/s11069-012-0161-1.

Scheibelofer, E., 2005. A reflection upon interpretive research techniques: the problemcentred interview as a method for biographic research. In: Narrative, Memory and Everyday Life. University of Huddersfield, Huddersfield, pp. 19-32.

Siebert, R., Toogood, M., Knierim, A., 2006. Factors affecting European farmers' participation in biodiversity policies. Sociol. Rural. 46 (4), 318-340.

Stiglbaeur, A.M., Weiss, C.R., 1999. Part-time farming and farm succession. In: Paper Presented at the IXth Congress of the European Association of Agricultural Economists in Developing Countries, Warsaw, Poland.

Smit, B., Skinner, M., 2002. Adaptation options in agriculture to climate change: a typology. Mitig. Adapt. Strategies Glob. Change 7 (1), 85-114.

Suess-Reyes, J., Fuetsch, E., 2016. The future of family farming: a literature review on innovative, sustainable and succession-oriented strategies. J. Rural Stud. 47, $117-140$.

Tierney, K.J., 1999. Toward a critical sociology of risk. Social Forum 14 (2), 215-242.

Uchiyama, T., Lobley, M., Errington, A., Yanagimura, S., 2008. Dimensions of intergenerational farm business transfers in Canada, England, the USA and Japan. Jpn. J. Rural Econ. 10, 33-48.

Veerman, C.P., Valverde Cabrero, E., Babuchowski, A., Bedier, J., Calzolari, G., Dobbin, D., Fresco, L.O., Giesen, H., Iwarson, T., Juhasz, A., Paumier, A.L., Šarmír, I., 2016. Improving market outcomes: enhancing the position of farmers in the supply chain. In: Report of the Agricultural Markets Task Force: Brussels, November 2016.

Vollenweider, X., Di Falco, S., O'Donoghue, C., 2011. Risk Preferences and Voluntary Agri-Environment Schemes: Does Risk Aversion Explain the Uptake of the Rural Environment Protection Scheme? Working Papers 48. Grantham Research Institute on Climate Change and the Environment, UK, London.

Ward, N., Lowe, P., 1994. Shifting values in agriculture: the farm family and pollution regulation. J. Rural Stud. 10 (2), 173-184.

Weston, W., 1977. The problem of succession. Farm Management 3, 237-246.

Whitehead, I., Lobley, M., Baker, J.R., 2012. From generation to generation: drawing the threads together. In: Lobley, M., Baker, M.J., Whitehead, I. (Eds.), Keeping it in the Family: International Perspectives on Succession and Retirement on Family Farms. 
Ashgate Publishing, Ltd.

Wilkinson, R., 2012. New patterns of succession in the Australian wool industry. In: Baker, J. (Ed.), 2012. Keeping it in the Family: International Perspectives on Succession and Retirement on Family Farms. Routledge, pp. 37-53.

Williams, F., 2006. Barriers Facing New Entrants to Farming - an Emphasis on Policy. Land Economy Working Paper Series. Land Economy Research Group, SAC, Aberdeen.

Wilson, G.A., 2001. From productivism to post-productivism...and back again? Exploring the (un)changed natural and mental landscapes of European agriculture. Trans. Inst. Br. Geogr. 26 (1), 77-102.

Witzel, A., 2000. The problem-centred interview. Forum Qual. Soc. Res. 1 (1) Article 22. Witzel, A., Reiter, H., 2012. The Problem-Centred Interview. Sage, London.

Zagata, L., Sutherland, L., 2015. Deconstructing the 'young farmer problem in Europe' towards a research agenda. J. Rural Stud. 38, 39-51. https://doi.org/10.1016/j. jrurstud.2015.01.003.

Zinn, J.O., 2017. The meaning of risk-taking - key concepts and dimensions. J. Risk Res. 1-15. https://doi.org/10.1080/13669877.2017.1351465.

Dr. Brian Leonard is a post-doctoral researcher at Teagasc. He completed an MA in Rural Sustainability at NUIG in 2013. Brian's doctoral research investigated farm succession and inheritance in Ireland. His research areas also include farm diversification, rural economic development, and agri-tourism.
Dr. Maura Farrell is a lecturer in the Geography Department at NUIG and director of the M.A in Rural Sustainability at NUIG. Her publications include research around agricultural advisory and rural development issues. She is currently involved in projects investigating the role of women in rural innovation and the development of rural towns.

Dr. Marie Mahon is a lecturer in the Geography Department at NUIG. Her research focuses on the nature of urban-rural change and development, and on issues of rural sustainability. She has published on urban-rural relationships and development, including the nature of civic engagement and governance, place-based identity and meaning and representations of rurality in fringe locations. She has also published on the governance of spatial planning, particularly issues of spatial justice and participatory democracy.

Anne Kinsella is a researcher at the Teagasc Rural Economy and Development Programme, Ireland. Within this she works in the Agricultural Economics and Farm Surveys Department. Her research interests include collaborative farming and agricultural policy.

Prof. Cathal O'Donoghue, Dean of Arts, NUIG. His research interests range from welfare economics to agricultural and economic policy. He has published widely in economic and agricultural journals. 